\title{
Digital Storytelling Design: Riau Malay Folklore
}

\author{
Sri Yuliani 1, Andi Idayani 2, Widia Yunita 3, Yulianto 4, Dicki Hartanto 5 \\ DOI: $10.35445 /$ alishlah.v13i3.961
}

\begin{tabular}{ll}
\hline Article Info & Abstract \\
\hline Keywords: & The purpose of this research was to find out the effectiveness and practicality of \\
Desian; & the product of digital storytelling in the online English classroom. The \\
Diqital; & researchers, previously, noticed that the varieties of media needed to be \\
Folklore; & developed in maintaining Malay folklore. This research offers insights into the \\
Malay; & effectiveness and practicality of digital storytelling in preserving Malay folklore. \\
Storytelling & This research is using a mixed-method quantitative and qualitative design. This \\
& research population was Islamic junior high school students in the first grade \\
& from three schools in Pekanbaru and eight pre-service English teachers involved \\
& in implementing the digital storytelling videos. The evaluation results showed \\
& that the design of digital storytelling videos showed the effectivity of digital \\
& storytelling products was high and practically on how digital storytelling videos \\
& were developed and applied in English class was also high. The implementation \\
& of digital storytelling videos was successfully done by the pre-service students \\
& and the appropriateness was high which can be used in the online English \\
& classroom.
\end{tabular}

Kata kunci:

Design;

Abstrak

Digital;

Folklore;

Malay;

Storytelling

Tujuan dari penelitian ini adalah untuk mengetahui keefektifan dan kepraktisan produk digital storytelling di kelas bahasa Inggris online. Peneliti sebelumnya melihat bahwa ragam media perlu dikembangkan dalam mempertahankan cerita rakyat Melayu. Penelitian ini menawarkan wawasan tentang efektivitas dan kepraktisan digital storytelling dalam melestarikan cerita rakyat Melayu. Penelitian ini menggunakan rancangan kuantitatif dan kualitatif campuran. Populasi penelitian ini adalah siswa SMP Islam kelas satu dari tiga sekolah di Pekanbaru dan delapan guru bahasa Inggris praktek yang terlibat dalam penerapan video digital storytelling. Hasil evaluasi menunjukkan bahwa desain video digital storytelling menunjukkan efektivitas produk digital storytelling tinggi dan secara praktis bagaimana video digital storytelling dikembangkan dan diterapkan di kelas bahasa Inggris juga tinggi. Implementasi video digital storytelling berhasil dilakukan oleh siswa prajabatan dan kesesuaiannya tinggi yang dapat digunakan di kelas bahasa Inggris online.

\footnotetext{
${ }^{1}$ Un iv ersitas Islam Riau, Pekanbaru, Indonesia

Em ail: sriyuliani@edu.uir.ac.id

2 Un iv ersitas Islam Riau, Pekanbaru, Indonesia

Em ail: andiidayani@edu.uir.ac.id

3 STA I Hubbulwathan, Duri, In donesia

Eail: widiayunita136@gmail.com

4 Universitas Islam Riau, Pekanbaru, In donesia

Em ail:yulianto@edu.uir.ac.id

5 Univ ersitas Islam Negeri Suska Riau, Pekanbaru, In donesia

Em ail: dicki.hartanto@uin-suska.ac.id

Vol.13(3) December, 2021

Received: August 11, 2021; Received in revised form: October 10, 2021; Accepted: November 5, 2021; Available on line: November 7, 2021

This is an open access article under a Creative Com mons Attribution-NonCom mercial-ShareAlike 4.0 In ternational License
} 


\section{INTRODUCTION}

Online learning is the same term as e-learning, web-based learning, virtual learning, internet learning, distance learning, cyberlearning, technology-based learning, and computer-based learning (Moore, J. L., Dickson-Deane, C., \& Galyen;2011, Aljhani et al., 2018). In the Covid-19 era, teachers have to develop many varieties of learning media that to be integrated with technology (S. Li, H. Du, W. Xing, J. Zheng, G. Chen, and C. Xie, 2020). Thus, teachers are recommended to continue their creativity and innovations.

Some research reported that many benefits of online learning system for the students like flexible learning experiences, synchronous and asynchronous communication systems, more interaction with peers, easily access to online learning sources, provide authentic learning (Davies, A; 2014, Fuller, P., \& Yu, 2014). Another benefit is that online learning gives opportunities to students to learn and study cultural experiences from other countries (Keengwe, J., Schnellert, G. L., \& Kungu, K, 2014).

The advantages from online learning system also share to the teachers that they get the flexibility in location and time, easily browse learning sources, easily assign the tasks, supervise, and instruct the students, and observe, listen, converse with the students' needs and complain (Baran, E., \& Correia, A. P, 2014). The learning process needs communication and interaction between learning components and learning resources. The learning resource provides students with information in various media forms regarding learning materials in images, videos, and software formats (A. Zakharov and O. Bondarenko, 2021), while learning components are one of the responsive courses that can be done through digital tools and can enhance learning in all scientific and academic contexts (G. Barzanò, P et al: 2017, S. Papadakis, M. Kalogiannakis, and N. Zaranis; 2017, M. Japar and D. Nur Fadhillah; 2018,), therefore, the teacher needs to design and create an education with technology (J. Walton, 2020).

Many learning sources might be used in the online learning system. The suitability of learning material in terms of digital storytelling is suggested as one possibility that places technology as a meaningful tool for teaching and learning (Alexandros Kapaniaris \& Spiros Sakarelos, 2020). Digital storytelling can increase the ability and confidence of students to enjoy and access independently, moreover, digital storytelling can help students to transfer their knowledge, skills and culture, thereby evolving their thinking process and helping them gain confidence (Robin, B.R, 2008).

Many types of research have been done to show that digital storytelling was suitable to be used in English class. Mokhtar, Kamarulzaman, \& Syed (2011) found that storytelling is one of the excellent ways to assist students to study four skills in their second language or foreign language because of the many benefits contained in stories, moreover, digital storytelling also enhances students' speaking skills in form of retelling stories. Other research showed that digital story telling also helps students in increasing their writing skills and their visual memory (Sarıca, H. Ç., \& Usluel, Y. K, 2016), storytelling is the best way to help the students learn the second language in the same way as their mother tongue which present parts of speech such as grammar and vocabulary in a meaningful context telling stories can be used as an area of reading comprehension and critical thinking in a group of storytelling (Sahibzada, $\lrcorner$ et al, 2020). The findings from the study done by Smeda, Dakich and Sharda (2014) suggested that digital storytelling was a powerful tool to integrate instructional messages with learning activities to create more engaging and exciting learning environments. It was a meaningful approach for creating a constructivist learning environment based on novel principles of teaching and learning. Thus, this approach had the potential to enhance student engagement and provide better educational outcomes for learners. The digital storytelling video Shelby-Caffey, Úbéda, and Jenkins (2014) found the benefit of digital storytelling that has been assigned to fifth-grade students to finish the project in writing in the 
elements of stories and the final product was in form of a movie that has been written by them based on that novel.

Other research findings revealed that the components used in creating digital storytelling in language learning were in kind of brainstorming, research projects, writing a story, presentations performance, improving interpersonal skills, solving problem-based tasks, and technology skills (Timuc, in, M., \& Irgin, 2015). The results finding of a positive effect of digital storytelling on the students' knowledge of educational technology for EFL students' astronomy disciplinary literacy acquisition and non-EFL students' disciplinary literacy acquisition in STEM areas (Chubko, N et al, 2020), in addition, the results research from Balaman (2018) of his study found that digital storytelling writing instruction showed a significant effect in increasing students' narrative writing skills and digital storytelling can help teachers who want to find out the students' needs and expectations in the 21st-century composition classes.

The evidence gathered from the previous research showed that digital storytelling positively affected students' problem-solving skills (Yang, Y.T. C., \& Wu, W.C, 2012), motivation, and 21stcentury literacy skills (Niemi, H et al, 2014). Findings from Kevser Hava (2019) showed that there were significant improvements in students' self-confidence from the calculation of paired t-test and it is also found that digital storytelling contributed a lot in learning vocabulary, writing and speaking skills, as the results showed that digital storytelling as an important and effective media that can be implemented in supporting the students' both language and digital skills.

Digital storytelling also shows a benefit on the students changing different forms of engaging action through giving, taking, sharing or limiting control in writing activities digitally. In the digital producing story phase, the students got experience in giving ideas, taking an idea, sharing a story, and having enjoyment and fun during producing digital story activities (Schmoelz, A, 2018). Other research findings showed that the digital literacy of pre-service teachers has improved, all of the findings obtained in terms of digital story creation and the contribution of the digital storytelling process to personal, technical and professional skills have highlighted the necessity of using digital story creation in educational environments differ significantly after the digital story creation process (Cetin E, 2020).

The components that make digital storytelling effective in language learning can be listed as brainstorming, doing research, writing, delivering presentations, improving interpersonal skills, solving problem-based tasks and using technology with multi-media tools (Timuçin, M., \& Irgın, P, 2015). In particular, it is reported that digital storytelling has significant advantages in terms of increasing students' interest and motivation in English (Kasami, N, 2018), and improving students' writing skills (Girmen, 2019), in addition, Fatih Tanrkulu (2020) revealed that digital storytelling improves the students' writing skills by proving his result finding on the student views that collaborative digital storytelling positively affects the composition of the text, thus the multimedia feature and the composition script have given positive effect on the student' writing.

Other research findings revealed that digital storytelling provided authentic and meaningful learning opportunities so that the students have chances to be proficient in speaking English and creative thinkers (Ya-Ting et al, 2020). The study found the effectiveness of digital storytelling as a tool in improving the students' reading skills, writing skills, listening skills, and speaking skills, thus digital storytelling is recommended to be implemented in English class because students enjoyed and actively participated engaging and improving their productive skills and receptive skills in English. In the activities of creating stories, students engaged with how to organize, cooperate and collaborate (Nassim, 2018).

Yang and $\mathrm{Wu}$ (2012) revealed that the effects of digital storytelling on students' academic achievement, their critical thinking, and their motivation in English as a foreign language education. The data was collected from a quasi-experimental class that the students were required to create digital stories about planets in groups while the control group students wrote compositions about the related topics and participated in class discussions. Findings showed that 
experimental group students were more successful in academic achievement, critical thinking and motivation domains.

Another study by Sahin, N., and Coban, İ (2020) found that the English academic achievement of the students in the courses in which digital storytelling are taught is higher than the achievement of the students in the courses taught compared to other teaching methods (used in the research included in the meta-analysis). This shows that the lessons taught using digital storytelling create a much more positive learning and teaching process than other teaching methods (used in the research included in the meta-analysis).

The findings of the study of digital storytelling also showed that there are statistically significant differences in students' academic achievement and students' motivation towards learning the English language due to teaching method in favour of experimental group which digital storytelling is the main method used in the English language. Statistically significant differences were also found in students' motivation towards learning the English language due to the teaching method in favour of the experimental group. In the light of the results, some recommendations were set like integrating digital storytelling in the teaching and learning English language (Aljaraideh, 2020).

Aware of this, the researchers realized that it is necessary to create one media that is used by English teachers and students to have fun and effective media to be used in online learning is digital storytelling. Digital storytelling is such integrated multiple elements involved like pictures/photographs, sound, music, movie maker, recording tools, text, and narration text audio. In this research, the researchers work on why digital storytelling is needed, then the design of digital storytelling is elaborated, last the analysis data of practicality on how digital storytelling impacts to English subject. So, the researchers set the purpose of this article is how digital storytelling the practicality of the product of digital storytelling as an educational media could help teachers and students to engage in educational content and to against Covid-19 situation.

\section{METHODS}

The design of digital storytelling in this research is using a mixed-method quantitative and qualitative design. Creswell (2018) said that Mixed methods involve the collection and "mixing" or integration of both quantitative and qualitative data in a study. It is not enough to only analyze qualitative and quantitative data but also consists of integrating the two databases for additional insight into research problems and questions. The samples were from two classes of Islamic junior high school students in implementing the Malay digital storytelling. Last, the development step was the implementation of digital storytelling in an English online class by 8 pre-service teacher students.

A mixed-method was used in this research with quantitative and qualitative data. The experimental class was used for quantitative data and an interview was used to collect qualitative data. There were two classes as experiment class and control class used in this research, first the students' result of studying by using Malay digital folklore in experiment class and other class as control class which did not get any treatment in its class. Eight pre-service teacher students implemented digital storytelling in the online classroom and two evaluators to access the appropriateness of digital storytelling. 


\section{FINDINGS AND DISCUSSION}

\section{The implementation of teaching English by using digital story telling}

Eight pre-service teacher students have implemented digital storytelling during practice teaching. The topics of digital storytelling were discussed and taught by them to junior high school for eight classes. Some questions were risen during an interview to get their preferred learning topics which was in five videos to be taught by them in the classroom. As a result of interviews, the pre-service teachers stated the digital storytelling help them a lot in conducting an online learning system, especially for English subject.

The result of the interview shows that the pre-service teachers' desires in using digital storytelling were quite high because they involved all skills in English. They said that digital storytelling involved all aspects that they were such as interactive videos (Anderson, K.T., \& Chua, P. H, 2020), and easy media to be used in the online system (Podara, A et al, 2021), they were presented in visual types involved all skills in English and they supported the improvement of students' vocabulary, reading skill, listening skill, speaking skill and writing skill (Arroba, J et el; 2021, Balaman, S; 2018, L. P. Rong \& N. M. Noor; 2019). Based on the research findings, it can be described that the development of digital storytelling was giving positive feedback from the users. Finally, the evidence research findings, it can be concluded that the digital storytelling which elaborated Suku Sakai was giving valuable impact to students in keeping Riau Malay heritage.

\section{The Result of the Effectivity of Malay Folklore Digital Story telling}

The result of the effectiveness of Malay folklore digital storytelling used data intended to test how significant the effect of using Malay folklore digital storytelling learning media on the learning outcomes of 20 first grade students of Islamic Junior high school in Pekanbaru as an experiment class. The results of the media effectiveness test are as follows:

Table 1: Learning Outcomes Before and After Using Malay folklore digital storytelling (Experiment class)

\begin{tabular}{|c|c|c|c|c|c|}
\hline No & Name & $\overline{\text { Pre-test }}$ & 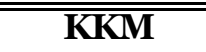 & $\overline{\text { Post-test }}$ & $\overline{\mathbf{K K M}}$ \\
\hline 1 & Student A & $\overline{80}$ & Completed & $\overline{91}$ & "Completed \\
\hline 2 & Student B & 75 & Completed & 95 & Completed \\
\hline 3 & Student C & 80 & Completed & 85 & Completed \\
\hline 4 & Student D & 70 & Completed & 80 & Completed \\
\hline 5 & Student E & 65 & Not & 75 & Completed \\
\hline 6 & Student F & 70 & Completed & 85 & Completed \\
\hline 7 & Student G & 75 & Completed & 80 & Completed \\
\hline 8 & Student H & 65 & Not & 75 & Completed \\
\hline 9 & Student I & 60 & Not & 70 & Not \\
\hline 10 & Student J & 65 & Not & 75 & Completed \\
\hline 11 & Student K & 80 & Completed & 85 & Completed \\
\hline 12 & Student L & 65 & Not & 75 & Completed \\
\hline 13 & Student M & 85 & Completed & 90 & Completed \\
\hline 14 & Student N & 85 & Completed & 90 & Completed \\
\hline 15 & Student O & 65 & Not & 75 & Completed \\
\hline 16 & Student P & 80 & Completed & 85 & Completed \\
\hline 17 & Student Q & 70 & Not & 80 & Completed \\
\hline 18 & Student R & 75 & Completed & 75 & Completed \\
\hline 19 & Student S & 60 & Not & 65 & Not \\
\hline 20 & Student T & 65 & Not & 75 & Completed \\
\hline
\end{tabular}

Based on the table above, we can see that there is a significant effect of the use of Malay folklore digital storytelling in experiment class. The table above shows that from a total of 20 students before implementing digital storytelling, 9 students did not complete the KKM, which means that the percentage of KKM in that class is $52 \%$. After the treatment, the use of digital storytelling increased the results of class learning outcomes to be $99 \%$ fulfilled the KKM. The result below is the calculation of $t$-test table of experiment class was calculated by SPSS software 
23 as follow:

Table 2. The Result of T-Test of Experiment class

\section{T-Test}

\begin{tabular}{|rl|c|r|r|c|}
\hline & & & & \multicolumn{1}{c|}{ Paired Samples Statistics } \\
& & Mean & \multicolumn{1}{c|}{$\mathrm{N}$} & Std. Deviation & \multicolumn{1}{c|}{ Mean } \\
\hline Pair 1 & Pre-Test & 71.7500 & 20 & 7.99260 & 1.78720 \\
& Post-Test & 80.3000 & 20 & 7.76022 & 1.73524 \\
\hline
\end{tabular}

The t-test table result above showed the average results of the pre-test and post-test showed a difference in results where the post-test results were higher (80.3) than the pre-test results (71.75), which means that there is a significant effect of digital storytelling.

Paired Samples Correlations

\begin{tabular}{|ll|r|r|c|}
\hline & N & Correlation & Sig. \\
\hline Pair 1 & $\begin{array}{l}\text { Pre-Test \& } \\
\text { Post-Test }\end{array}$ & 20 & .848 & .000 \\
\hline
\end{tabular}

From the significance value (Sig) of the pre-test and post-test correlation results of 0.00 which means it is smaller than 0.05 , so it can be concluded that there is a significant effect of the results between the pre-test and post-test.

\section{Paired Samples Test}

\begin{tabular}{|c|c|c|c|c|c|c|c|c|c|}
\hline & \multicolumn{5}{|c|}{ Paired Differences } & \multirow[b]{3}{*}{$\mathrm{t}$} & \multirow[b]{3}{*}{$\mathrm{df}$} & \multirow[b]{3}{*}{$\begin{array}{l}\text { Sig. (2- } \\
\text { tailed) }\end{array}$} \\
\hline & & \multirow[b]{2}{*}{ Mean } & \multirow{2}{*}{$\begin{array}{c}\text { Std. } \\
\text { Deviat } \\
\text { ion } \\
\end{array}$} & \multirow{2}{*}{$\begin{array}{l}\text { Std. } \\
\text { Error } \\
\text { Mean } \\
\end{array}$} & \multicolumn{2}{|c|}{\begin{tabular}{|c}
$95 \%$ Confidence \\
Interval of the \\
Difference \\
\end{tabular}} & & & \\
\hline & & & & & Lower & $\begin{array}{c}\text { Uppe } \\
\mathrm{r}\end{array}$ & & & \\
\hline $\begin{array}{l}\text { Pair } \\
1\end{array}$ & $\begin{array}{l}\text { Pre-Test } \\
\text { - Post- } \\
\text { Test }\end{array}$ & $\begin{array}{r}8.5500 \\
0 \\
\end{array}$ & $\begin{array}{r}4.346 \\
50\end{array}$ & .97191 & - & $\begin{array}{r}6.515 \\
77 \\
\end{array}$ & $\begin{array}{r}- \\
8.797\end{array}$ & 19 & .000 \\
\hline
\end{tabular}

From the significance value (2-tailed) between the pre-test and post-test values obtained a value of 0.00 which means less than 0.05 , it can be concluded that there is a difference in the results between the pre-test and post-test in the experimental class.

Based on $\mathrm{df}=40-2=38$ at a significant level of $5 \%$, a ttable of 2.03 was obtained and at a significant level of $1 \%$, a t-table of 2.72 was obtained. With tcount of 8.797 , which means that it is greater than ttable, both at the significant level of $5 \%$ and the significant level of $1 \%(2.03<8.797>$ 2.72), then Ho is rejected. In other words, there is a significant difference between student learning outcomes between pre-test and post-test in the experimental class.

The result of the effectiveness of Malay folklore digital storytelling in control class is as follows: 
Table 3. Learning Outcomes Before and After Using Malay folklore digital storytelling (Control class)

\begin{tabular}{|c|c|c|c|c|c|}
\hline No & Name & Pre-test & KKM & Post-test & $\overline{\mathbf{K K M}}$ \\
\hline 1 & StudentA & 75 & Completed & $\begin{array}{l}75 \\
\end{array}$ & Completed \\
\hline 2 & Student B & 75 & Completed & 80 & Completed \\
\hline 3 & StudentC & 65 & Not & 65 & Not \\
\hline 4 & Student D & 70 & Completed & 75 & Completed \\
\hline 5 & StudentE & 60 & Not & 70 & Not \\
\hline 6 & Student F & 80 & Completed & 85 & Completed \\
\hline 7 & Student G & 70 & Not & 80 & Completed \\
\hline 8 & Student H & 75 & Completed & 75 & Completed \\
\hline 9 & Student I & 75 & Completed & 75 & Completed \\
\hline 10 & StudentJ & 60 & Not & 70 & Not \\
\hline 11 & Student K & 60 & Not & 65 & Not \\
\hline 12 & Student L & 65 & Not & 70 & Not \\
\hline 13 & Student M & 70 & Not & 70 & Not \\
\hline 14 & Student N & 70 & Not & 70 & Not \\
\hline 15 & StudentO & 75 & Completed & 75 & Completed \\
\hline 16 & Student P & 75 & Completed & 80 & Completed \\
\hline 17 & StudentQ & 60 & Not & 60 & Not \\
\hline 18 & Student R & 85 & Completed & 85 & Completed \\
\hline 19 & StudentS & 75 & Completed & 75 & Completed \\
\hline 20 & StudentT & 85 & Completed & 85 & Completed \\
\hline
\end{tabular}

Based on the table above that there is not a significant effect for the control class. The table above shows that a total of 20 students did not get any treatment to fulfil the KKM, which means that the percentage of KKM in that class is $32 \%$.

The data below is the result of the Independent Samples Test (T-Test Table) was using SPSS software 23.

\section{Table 4. The Result of T-Test of Control class}

\section{T-Test}

Paired Samples Statistics

\begin{tabular}{|ll|l|r|r|c|}
\hline & & Mean & N & Std. Deviation & $\begin{array}{c}\text { Std. Error } \\
\text { Mean }\end{array}$ \\
\hline Pair 1 & Pre-Test & 71.2500 & 20 & 7.75870 & 1.73490 \\
& Post-Test & 74.2500 & 20 & 6.93485 & 1.55068 \\
\hline
\end{tabular}

The data above showed that the average results of the pre-test and post-test seen in the control class did not show any difference in learning outcomes were the results of the pre-test (71.25) and post-test were not significantly different (74.25).

Paired Samples Correlations

\begin{tabular}{|ll|r|r|c|}
\hline & \multicolumn{1}{|c|}{$\mathrm{N}$} & Correlation & \multicolumn{1}{c|}{ Sig. } \\
\hline Pair 1 & Pre-Test \& Post-Test & 20 & .474 & .062 \\
\hline
\end{tabular}

From the significance value (Sig) of the pre-test and post-test correlation results of 0.062 which means it is smaller than 0.05, so it can be concluded that there is no significance in the results between the pre-test and post-test. 


\section{Paired Samples Test}

\begin{tabular}{|c|c|c|c|c|c|c|c|c|}
\hline & \multicolumn{5}{|c|}{ Paired Differences } & $\mathrm{t}$ & df & $\begin{array}{l}\text { Sig. (2- } \\
\text { tailed) }\end{array}$ \\
\hline & \multirow[b]{2}{*}{ Mean } & \multirow{2}{*}{$\begin{array}{l}\text { Std. } \\
\text { Deviat } \\
\text { ion } \\
\end{array}$} & \multirow{2}{*}{$\begin{array}{l}\text { Std. } \\
\text { Error } \\
\text { Mean } \\
\end{array}$} & \multicolumn{2}{|c|}{$\begin{array}{c}\text { 95\% Confidence } \\
\text { Interval of the } \\
\text { Difference }\end{array}$} & & & \\
\hline & & & & Lower & Upper & & & \\
\hline $\begin{array}{ll}\text { Pair } & \text { Pre- } \\
1 & \text { Test - } \\
& \text { Post- } \\
& \text { Test }\end{array}$ & $\begin{array}{r}- \\
3.00 \\
000\end{array}$ & $\begin{array}{r}3.769 \\
69\end{array}$ & .84293 & $\begin{array}{r}- \\
4.764 \\
27\end{array}$ & -1.23573 & $\begin{array}{r}- \\
2.559\end{array}$ & 19 & .062 \\
\hline
\end{tabular}

The data above showed that the significance value (2-tailed) between the pre-test and posttest values obtained a value of 0.062 which means greater than 0.05 , it can be concluded that there is no significant effect on the results between the pre-test and post-test in the control class.

Based on the calculation of $\mathrm{df}=40-2=38$ at a significant level of $5 \%$, a $t_{\text {tabel }}$ of 2.03 was obtained and at a significant level of $1 \%$, a $t_{\text {tabel }}$ of 2.72 was obtained. With a thitung of 2,559 which means that it is greater than $t_{\text {tabel }}$ both at the $5 \%$ significant level and $1 \%$ significant level $(2.03<$ $2.559<2.72$ ), then $\mathrm{H}_{\mathrm{o}}$ is rejected. In other words, there is no significant effect between student learning outcomes between pre-test and post-test in the control class in implementing digital storytelling.

\section{The Practicality of Digital Storytelling}

This project was mainly to introduce this ancient story to millennial students to be known all over Riau Province. The data of the impact of digital storytelling was taken from two computer programmers in accessing the product. The purpose of this practicality was to find out the computer programmers about their evaluation on the aspects of convenience usage, the benefit of using it, the attractiveness and the clarity of its visual communication in using digital storytelling.

\begin{tabular}{lccc}
\multicolumn{4}{c}{ Table 5. Results of Practicality from Pre-Service Students } \\
\hline No & Components Value & Practicality & Criteria \\
& & Assessment & \\
\hline 1 & Convenience & 80.63 & High \\
2 & Benefits & 81.88 & Very High \\
3 & Attractiveness & 80.50 & High \\
4 & Clarity of visual & 80.75 & High \\
& Average & 80.94 & High \\
\hline
\end{tabular}

Based on the practical results in table 5 above, the convenience of Digital Storytelling was 80.63 in high-level criteria. Benefits were 81.88 in very high-level criteria, then attractiveness was 80.50 means that it was in high-level criteria and last clarity of visual communication was 80.75 in high-level criteria. The average score for practicality gained 80.94 in high-level criteria. It means that this digital storytelling of its practicality showed that digital storytelling was practical, thus digital storytelling made students easier to understand learning materials.

The research findings have shown that it is needed to design digital storytelling to attract millennial students to love Riau Malay heritage. The analyses of the result data showed that most students agreed to design a new model of maintaining Malay folklore in digital storytelling. It relies on the analyses of the needs of maintaining culture is important for millennial students however 
most of them attend to watch Korean Drama, Korean Pop, Hollywood film, and -the non-original storey from Indonesia. Based on the analyses, it is necessary to design digital storytelling.

The planning issued from the researcher's idea to collect Suku Sakai's folklore and they had been collected from the inland tribe and stored in a special file. The first project for this research was developed one story of Suku Sakai was one of several communities of forest-dwelling that lived in the upstream river regions of Malay kingdoms on both sides of the Straits of Malacca and Riau island. The design of digital storytelling in this research was using the Wondershare Filmora9 application program which easily created videos and learning media with Wondershare filmora9. Wondershare Filmora9 is the Software used to make movies, making it easier for us to make our videos by providing a variety of built-in templates, filled with fashion features that come with all timelines, you can customize it with various features to set the scene and edit video (Wondershare, 2019). Wondershare Filmora software is a lot used by YouTubers as well as for commercial videos, but in this study, researchers will present a video in the form of learning in the form of videos. The wondershare Filmora9 assisted the researchers in designing the digital storytelling.

The development of digital storytelling followed each step of the Wondershare Filmora application program. Each step had been followed and the product of digital storytelling had been produced. Five videos had been produced with sequence stories from Suku Sakai folklore. Each video had been used a different native speakers sound. Three videos with female native speakers sound and two male native speakers sound. The images represented in the digital storytelling was taken from the images of Suku Sakai daily activities then the text was inserted to teach millennial students English vocabularies.

\section{CONCLUSION}

This development model research has produced five videos of digital storytelling of Suku Sakai that was taken from old Malay folklore in the inland area of Riau. These videos will be implemented in English subjects shortly. This first project of digital storytelling has given a variety of learning material in English subjects. Based on the findings that the needs of millennial students with new content of folklore and sound uncommon already attracted their attention in digital folklore. Switching from Kpop, Korean Drama and its like, the researchers turned the millennial students to digital folklore, so the Malay heritage is retained and new unique stories become substitute concern. The planning and the development of digital storytelling products found a variety of problems about software, in terms of time allocation, sounds chosen and images insertion. These technical problems are solved by the system analyst. Five videos of digital storytelling were tried by eight pre-service students and it found that digital storytelling practically helped them to use this first project in their online class in shortcoming events. They already decided that the product in this research will be used as one media to support their teaching material shortly in this coming even semester 2021. The time and source of old Malay folklore became the limitation of the research because the researchers might involve in digging and searching for more stories of Malay folklore. Hopefully, this research will give a bright image of how to find the old Malay folklore in the inland of Riau. The researchers suggest to the next researchers involved in enriching Malay folklore to be explored more, thus many old Malay folklore will be found and introduced to our young generations.

\section{REFERENCES}

A. Zakharov and O. Bondarenko. (2021). Social status and social learning. J. Behav. Exp. Econ. , vol. 90, p. 101647. DOI:10.1016/j.socec.2020.101647

Aljuhani, Khulood Owid, Abbas, Samah Anwar, \& AbdulAziz, Azrilah. (2018). Review of Information Quality of E-learning Systems in Saudi Arabia. International Advanced Research Journal in Science, Engineering and Technology, 5(5), 43-50. https://www.researchgate.net/publication/325553519_Review_of_Information_Quality_o f_E-learning_Systems_in_Saudi_Arabia 
Alessi, S.M., \& Trollip, S.R. (2001). Multimedia for Learning.Methods and Developments, 3rd Ed. Needham Heights, Massachusetts: Allyn \& Bacon. https://www.pearson.com/us/highereducation/program/Alessi-Multimedia-for-Learning-Methods-and-Development-3rdEdition/PGM144366.html

Anderson, K.T., \& Chua, P. H. (2020). Digital Storytelling as an interactive digital media context: Technology in transparent support of creative media production. Educational Technology, 50(5), 32-36. https://www.academia.edu/2203691/Digital Storytelling as an Interactive Digital Me dia Context

Arroba, J., \& Acosta, H. (2021). Authentic digital storytelling as alternative teaching strategy to develop speaking skills in EFL classes. LEARN Journal: Language Education and Acquisition Research Network, 14(1),317-343. $\underline{\text { https://so04.tci- }}$ thaijo.org/index.php/LEARN/index

Balaman, S. (2018). Digital storytelling: A multimodal narrative writing genre. Journal of Language and Linguistic Studies, 14(3), 202-212. Available online at www.jlls.org

Baran, E., \& Correia, A. P. (2014). A professional development framework for online teaching. TechTrends, 58(5), 95-101.https://doi.org/10.1007/s11528-014-0791-0

Cetin E. (2020). Digital storytelling in teacher education and its effect on the digital literacy of preservice teachers. Thinking Skills and Creativity. doi: https://doi.org/10.1016/j.tsc.2020.100760

Chubko, N., Morris, J. E., McKinnon, D. H., Slater, E. V., \& Lummis, G. W. (2020). Digital storytelling as a disciplinary literacy enhancement tool for EFL students. Educational Technology Research and Development, 1-18. https://doi.org/10.1007/s11423-020-09833$\underline{x}$

Davies, A. (2014). Integrating e-learning to improve learning outcomes: a proven way for teachers to engage students and improve learning outcomes is through the appropriate use of elearning and Web 2.0 tools in teaching. Planning for Higher Education Journal, 42(4), 2329.

https://www.thefreelibrary.com/Integrating+elearning+to+improve+learning+outcomes\% $3 a+a+$ proven+way+for...-a0389507794

Fuller, P., \& Yu, G. (2014). Lessons learned: online teaching adventures and misadventures. Journal of Social Sciences, 10(1), 33-38.https://doi.org/10.3844/jssp.2014.33.38

G. Barzanò, P. Cortiana, I. Jamison, M. Lissoni, and L. Raffio. (2017). New means and new meanings for multicultural education in a global-Italian context. Multicult. Educ. Rev., vol. 9, no. 3, pp. 14.5-158. https://doi.org/10.1080/2005615x.2017.13465.54

Girmen, P.; Özkanal, Ü.; Dayan, G. (2019). Digital Storytelling in the Language Arts Classroom. Univ.J.Educ. Res. 2019,7,55-65. DOI:10.13189/ujer.2019.070108

Hava, K. (2019). Exploring the role of digital storytelling in student motivation and satisfaction in EFL education. Computer Assisted Language Learning, 121. doi:10.1080/09588221.2019.1650071

J. Walton. (2020). The limits of 'multiculturalism without diversity': multi-ethnic students and the negotiation of 'difference' in South Korean schools. Ethn. Racial Stud., vol. 43, no. 5, pp. 835-853.https://doi.org/10.1080/01419870.2019.1643034

Kapaniaris, A \& Sakarelos, S. (2020). History Archives: Digital Storytelling as a Public History ReNarration Tool. WWJMRD 202O; 6(3): 26-31. http://wwimrd.com/upload/local-historyarchives-digital-storytelling-as-a-public-history-re-narration-tool $1585926387 . \mathrm{pdf}$

Kasami, N. (2018). Advantages and disadvantages of digital storytelling assignments in EFL education in terms of learning motivation. In P. Taalas, J. Jalkanen, L. Bradley \& $S$. Thouësny (Eds), Future-proof CALL: language learning as exploration and encounters short papers from EUROCALL 2018 (pp. 130-136). Research-publishing.net. https://doi.org/10.14705/rpnet.2018.26.825

Keengwe, J., Schnellert, G. L., \& Kungu, K. (2014.). Cross-cultural Online Learning in Higher Education and Corporate Training. IGI Global. DOI:10.4018/978-1-4666-5023-7

L. P. Rong and N. M. Noor. (2019). Digital Storytelling as a Creative Teaching Method in Promoting Secondary School Students' Writing Skills. International Journal Interacting Mobile Technology,vol.13, no.7.https://doi.org/10.3991/ijim.v13io7.10798 
Lwin, S. M. \& Marlina, R. (2018). Using folktales as a way to operationalise the paradigm of teaching English as an International Language. Asian Englishes,1-14. DOI: 10.1080/13488678.2018.1440279

M. Japar and D. Nur Fadhillah. (2018). Do We Need to Learn About Human Rights Values?. Jurisprudential Inquiry Model of Teaching in Senior High School. https://doi.org/ $\underline{10.2991 / i c l i-17.2018 .19}$

Mokhtar, N. H., Kamarulzaman, M. F. A. H., \& Syed, S. Z. (2011). The effectiveness of storytelling in enhancing communicative skills. Procedia - Social and Behavioral Sciences, 18, 163-169. DOI:10.1016/J.SBSPRO.2011.05.024

Moore, J. L., Dickson-Deane, C., \& Galyen, K. (2011). E-Learning, online learning, and distance learning environments: Are thev the same?. The Internet and Higher Education, 14(2), 129135. https://doi:10.1016/j.iheduc.2010.10.001

N Abd Rahim. (2014). Nearly Forgotten Malay Folklore: Shall We Start with the Software?. Turkish Online Journal of Educational Technology-TOJET 13 (3), 2014, pp. 216-221. https://files.eric.ed.gov/fulltext/EJ1034241

Nassim, S. (2018). Digital Storytelling: An Active Learning Tool for Improving Students' Language Skills. PUPIL: International Journal of Teaching, Education and Learning, 2(1),14-27. DOI-https://dx.doi.org/10.20319/pijtel.2018.21.1427

Niemi, H., Hariu, V., Vivitsou, M., Viitanen, K., Multisilta, J., \& Kuokkanen, A. (2014). Digital Storytelling for 21st-Century Skills in Virtual Learning Environments. Creative Education, 5(9), 657-671. https://doi.org/10.4236/ce.2014.59078

Podara, A.; Giomelakis, D.; Nicolaou, C.; Matsiola, M.; Kotsakis, R. (2021). Digital Storytelling in Cultural Heritage: Audience Engagement in the Interactive Documentary New Life. Sustainability 2021,1.3, 119.3. https://doi.org/10.3390/su130.31193

Porath, Nathan. (2018). The Orang Batin/Orang Sakai in the Malay Kingdom of Siak Sri $\begin{array}{lllll}\text { Indrapura. Asian Ethnology, } 77 \quad \text { (1/2), } & \text { 285-306. }\end{array}$ http://eprints.soton.ac.uk/id/eprint/439294

R Benmayor. (2008). Digital storytelling as a signature pedagogy for the new humanities. Arts Humanit High Educ 7(2), 188-204. https://doi.org/10.1177/1474022208088648

Robin, B.R. (2008). Digital storytelling: A powerful technology tool for the 21st century classroom. Theory into Practice, 47(3), 220-228. DOI:10.1080/00405840802153916

S. Li, H. Du, W. Xing, J. Zheng, G. Chen, and C. Xie. (2020). Examining temporal dy namics of selfregulated learning behaviors in S.T.E.M. learning: A network approach. Comput. Educ., vol. 158, no. July, p. 103987.https://doi.org/10.1016/i.compedu.2020.103987

S. Papadakis, M. Kalogiannakis, and N. Zaranis. (2017). Designing and creating an educational app rubric for preschool teachers. Educ. Inf. Technol, vol. 22, no. 6, pp. 3147-3165. https://doi.org/10.1007/s10639-017-9579-0

Sahibzada, J., Ahmadzai, Y. M. B., Niaz, A., \& Laftah, S. H. (2020). Effects of Storytelling on Improving EFL Students' Critical Thinking and Reading Comprehension. American International Journal of Social Science Research, 5(1), 33-47. https://doi.org/10.46281/aijssr.v5i1.485

Sahin, N., and Coban, İ. (2020). The effect of digital story applications on students' academic achievement: A meta-analysis study. African Educational Research Journal, 8(3): S62-S75. DOI: $10.30918 /$ AERJ.8S3.20.047

Sarıca, H. C.., \& Usluel, Y. K. (2016). The effect of digital storytelling on visual memory and writing $\begin{array}{llll}\text { skills. } \quad \text { Computers Education, 298-309. } & \text { 94, }\end{array}$ https://doi.org/10.1016/i.compedu.2015.11.016

Schmoelz, A. (2018). Enabling co-creativity through digital storytelling in education. Thinking Skills and Creativity, 28, 13. doi:10.1016/j.tsc.2018.02.002 https://doi.org/10.1016/j.tsc.2018.02.002

Shelby-Caffey, C., Úbéda, E., \& Jenkins, B. (2014). Digital storytelling revisited: An educator's use of innovative literacy practice. The Reading Teacher, 68(3), 191-199. doi:10.1002/trtr.1273

Sim, Bryson. (2020). A beginners Guide to Filmora 9. United States. Lulu 3101 Hillsborough Street Raleigh, Nc 27607. https://www.udemy.com/Filmora/Online-Coursei18.16631

Smeda, N., Dakich, E. \& Sharda, N. (2014). The effectiveness of digital storytelling in the classrooms: a comprehensive study. Smart Learn. Environ. 1, 6. https://doi.org/10.1186/s40561-014-0006-3 
Tanrıkulu, F. (2020). Students' perceptions about the effects of collaborative digital storytelling on writing skills. Computer Assisted Language Learning, 116. doi:10.1080/09588221.2020.1774611

Timuçin, M., \& Irgın, P. (2015). Digital storytelling: An outlet for expression in EFL context. International Journal of Languages' Education and Teaching, 3(1), 288-302. oai:doaj.org/article:5144ffe.3c1df4050b65b11edf7e1e96d

Ya-Ting, Carolyn Yang, Yi-Chien Chen \& Hsiu-Ting Hung. (2020). Digital storytelling as an interdisciplinary proiect to improve students' English speaking and creative thinking. Computer Assisted Language Learning, 16. DOI: $10.1080 / 09588221.2020 .1750431$

Yang, Y.-T. C., \& Wu, W.-C. I. (2012). Digital storytelling for enhancing student academic achievement, critical thinking, and learning motivation: A year-long experimental study. Computers \& Education, 59(2), 339-352. https://doi.org/10.1016/j.compedu.2011.12.012

Yoon, T. (2012). Are you digitized? Ways to provide motivation for ELLs using digital storytelling. Intermational Journal of Research Studies in Educational Technology, 2(1), 25-34.DOI: $\underline{10.5861 / \text { ijrset.2012.204 }}$

Yousef Ahmad ALJARAIDEH. (2020). The Impact of Digital Storytelling on Academic Achievement of Sixth Grade Students in English Language and Their Motivation Towards it in Jordan. Turkish Online Journal of Distance Education-TOJDE January 2020 ISSN 1302-6488 Volume: 21 Number: 1 Article 6. EJ1239007.pdf(ed.gov) 